\title{
Guidelines in the Register of the Association of Scientific Medical Societies in Germany - A Quality Improvement Campaign
}

\author{
Leitlinien im Register der AWMF - eine Qualitätsinitiative der Fachgesellschaften
}

Authors

Affiliation
M. J. Nothacker, C. Muche-Borowski, I. B. Kopp

AWMF-IMWi, Marburg

\begin{abstract}
Key words
- guidelines

- development

- evidence-based

- consensus process

- conflicts of interest

Schlüsselwörter

- Leitlinien

- Entwicklung

- Evidenzbasierung

- Konsensfindung

- Interessenkonflikte
\end{abstract}

Deutschsprachige Zusatzinformationen online abrufbar unter: www.thieme-connect.de/ ejournals/toc/gebfra received $\quad 6.1 .2014$ revised $\quad 5.2 .2014$ accepted $\quad 6.2 .2014$

\section{Bibliography}

Dol http://dx.doi.org/ 10.1055/s-0034-1368227

Geburtsh Frauenheilk 2014; 74: 260-266 @ Georg Thieme

Verlag KG Stuttgart · New York . ISSN 0016-5751

\section{Correspondence}

Dr. Monika J. Nothacker,

Dr. med., M.P. H.

AWMF-IMWi

Karl-von-Frisch-Straße 1

35043 Marburg

nothacker@awmf.org

\section{Abstract \\ $\nabla$}

The Association of Scientific Medical Societies in Germany (AWMF) is the umbrella organization of medical scientific societies in Germany. The development of guidelines goes back to an initiative of the medical scientific societies and is coordinated by the AWMF. Rules for the inclusion of guidelines in the AWMF Guideline Register have been defined including how guidelines are classified. S1 guidelines are based only on recommendations by experts, whereas $\mathrm{S} 2$ guidelines require a structured consensus process or a systematic literature review. S3 guidelines include both elements. In addition to compulsory disclosure of any potential conflict of interest, transparent handling of potential conflicts of interest is an important confidence-building measure. For years, the trend has been to develop higher order (S2/S3) guidelines, and the German Society for Gynecology and Obstetrics (DGGG) has been no exception to the trend. In addition to its responsibility for specific S2 and S3 guidelines, the DGGG is also involved in numerous other interdisciplinary guidelines. When developing a guideline, it is essential to define the guideline's scope, identify aspects which require improvement and agree on the goals. Target groups affected by the guidelines should be involved if they are interested. Different formats (long and short versions, practical instructions, conventional or electronic decision aids, patient versions) are useful to disseminate the guideline. The guideline can be adapted to local circumstances to encourage implementation of its recommendations. Implementation can be measured using quality indicators. Feedback from practitioners is important as this highlights areas which require improvement. The medical scientific societies in Germany can look back on almost two decades of work spent on developing guidelines, most of it done by unpaid voluntary contributors, making this a very successful quality initiative.

\section{Zusammenfassung \\ $\nabla$}

Die Arbeitsgemeinschaft der Wissenschaftlichen Medizinischen Fachgesellschaften (AWMF) vertritt als Dachverband die Interessen der Fachgesellschaften nach außen. Die Entwicklung von Leitlinien ist eine Initiative der Fachgesellschaften, die durch die AWMF koordiniert wird. Das AWMF-Leitlinienregister unterliegt definierten Regeln, dazu gehört auch die Klassifikation der Leitlinien. Während S1-Leitlinien reine Expertenempfehlungen sind, weisen S2-Leitlinien ein formales Konsensverfahren oder eine systematische Literaturbasierung auf. S3-Leitlinien zeichnen sich durch beide Elemente aus. Weiterhin ist neben der obligaten Offenlegung der Umgang mit potenziellen Interessenkonflikten eine wichtige vertrauensbildende Maßnahme. Seit Jahren ist eine Entwicklung zu höherwertigen Leitlinien (S2/S3) sichtbar, diese zeigt sich auch bei der Deutschen Gesellschaft für Gynäkologie und Geburtshilfe (DGGG). Neben der Federführung bei S2- und S3-Leitlinien ist die DGGG an zahlreichen weiteren interdisziplinären Leitlinien beteiligt. Bei der Leitlinienentwicklung sind die sinnvolle Eingrenzung des Themas, das Eruieren von Verbesserungspotenzial und das Festlegen von Zielen wesentlich. Die Adressaten sollten bei Interesse eingebunden werden. Für die erfolgreiche Verbreitung sind verschiedene Formate (Lang-, Kurzfassung, Praxishilfen, Patientenversionen, ggf. elektronische Entscheidungshilfen) hilfreich. Um die Implementierung zu fördern, kann die Leitlinie an lokale Gegebenheiten angepasst werden. Die Umsetzung kann über Qualitätsindikatoren gemessen werden. Wichtig sind Rückmeldungen aus der Praxis zur Erkennung von Verbesserungsbedarf. Die Fachgesellschaften können inzwischen auf fast 2 Jahrzehnte überwiegend ehrenamtlicher Leitlinienarbeit zurückblicken - eine erfolgreiche Qualitätsinitiative. 


\section{Quality Development in the German Healthcare System: Responsibilities and Duties of the AWMF $\nabla$}

The Association of Scientific Medical Societies (German: Arbeitsgemeinschaft der Wissenschaftlichen Medizinischen Fachgesellschaften e.V., abbreviated AWMF) was set up in 1962 as the German umbrella organization of scientific medical societies in Germany [1]. Currently, 168 scientific medical societies are members of the AWMF. The goal of the AWMF was and is to raise the public profile of medical science and to promote the interests of medical science when dealing with governmental bodies and institutions of the German self government in health care. The AWMF has 3 permanent committees: the Guidelines Committee, the Committee for Performance Assessment in Research and Teaching and the Admissions Committee. The executive committee of the AWMF also sets up ad-hoc committees when required as was done in 2010 to consider the topic "conflict of interest". The AWMF has also set up the working groups "physicians and lawyers" and "hygiene in hospitals and private practices" to cover 2 important areas. Together with the German Institute for Medical Documentation and Information (German: Deutsches Institut für Medizinische Dokumentation und Information, abbreviated DIMDI) and the German Central Library for Medicine (German: Deutsche Zentralbibliothek für Medizin, abbreviated ZB MED) the AWMF maintains the portal "German Medical Science" (GMS) and the eponymous e-journal "German Medical Science" (gms) to promote free access to important research (open access publishing).

\section{Representing the interests of medical societies}

\section{and coordinating their statements}

Representatives of the AWMF represent the interests of the German medical societies in the German Health Research Council, the board of the Institute for Quality and Efficiency in Healthcare (IQWiG), the board and academic advisory council of the National Institute for Quality Assurance (AQUA Institute), in committees of the German Medical Association, (e.g., committees on advanced medical training and health services research), and in the National Cancer Plan [1]. The AWMF delivers opinions on planned laws, drafts of the IQWiG (e.g., on the Method Paper), the AQUA Institute (e.g., on standards for external comparative quality assurance) and the Robert Koch Institute (e.g., on guidelines and drafts of recommendations on genetic diagnostics, hospital hygiene and the prevention of infection) as well as on planned European regulations [2]. Since 2012, the AWMF has been authorized to comment on directives issued by the Federal Joint Committee (German: Gemeinsamer Bundesausschuss, abbreviated G-BA) in accordance with Articles 135, 137c and 137e of the German Code of Social Law, Book V (SGB V) [3]. The AWMF plays an important role in coordinating and promoting the interests of its member societies by providing information to medical societies and collating and summarizing statements on specific topics.

\section{Supporting and coordinating guidelines}

In Germany, the idea of drawing up guidelines was triggered by a special report of the Expert Advisory Board for Concerted Action in Healthcare published in 1995. In contrast to other countries where work on governmental guideline programms are underway, the responsibility and authority to develop guidelines in Germany was permanently entrusted to medical scientific societies. At the same time, the AWMF as their umbrella organization was given the mandate to expedite and coordinate the process [4]. The tasks and aims of the AWMF in developing guidelines include

- providing access to high-quality interdisciplinary guidelines in the Guideline Register of the AWMF (www.awmf.org/leitlinien. html),

- recognizing when guidelines in different areas of healthcare are necessary (setting priorities),

- supporting medical societies when they draw up or update guidelines,

- contributing to expertise in medical societies by offering training and skills enhancement for guideline consultants,

- providing a body of rules for drawing up and updating guidelines.

Together with the German Medical Association and the Federal Association of Statutory Health Insurance Physicians (German: Kassenärztliche Bundesvereinigung), the AWMF is responsible for the Program for National Disease Management Guidelines (German: Programm für Nationale Versorgungsleitlinien, abbreviated NVL). Together with the German Cancer Society (German: Deutsche Krebsgesellschaft) and German Cancer Aid (Deutsche Krebshilfe) the AWMF is responsible for the guideline program Oncology (OL). But the overwhelming majority of guidelines in the AWMF Register are the result of individual initiatives and are mainly financed by individual medical societies themselves. The AWMF supports and advises its member societies and publishes guidelines free of charge in its Guideline Register. To ensure that the Guideline Register remains a reliable source of information, the methodological quality is reviewed for all guidelines included in the Register. Since 2009, the AWMF Institute for Knowledge Management (German: AWMF-Institut für Wissensmanagement, abbreviated AWMF-IMWi) has been responsible for maintaining the Register. However, the individual medical societies are responsible for the content of the respective guidelines.

\section{Development of Guidelines - Rationale and Duties of Medical Societies and Authors \\ $\nabla$}

The primary aim of guidelines is to improve medical healthcare by providing and disseminating the most up-to-date knowledge. Making guidelines generally available acknowledges the fact that individual physicians rarely have the time to keep abreast of all the latest developments and publications and to additionally critically appraise studies. Just to give an example, around 25000 randomized clinical studies were published every year between 1994 and 2001 in the medical database MEDLINE alone [5]. A healthy skepticism about the resilience of study results and the transferability of results to important patient groups is often advisable [6-8].

Guidelines are "systematically developed statements which support physicians and patients when making decisions about proper and suitable healthcare for specific health issues." [9]. Guidelines should provide clinicians with a systematic assessment of recent and current literature (evidence) $[5,10]$.

In summary, guideline authors should

- depict the current state of knowledge, consisting of the scientific evidence and the practical experience of experts with regard to specific problems,

- assess this body of knowledge from a methodological and clinical standpoint, 

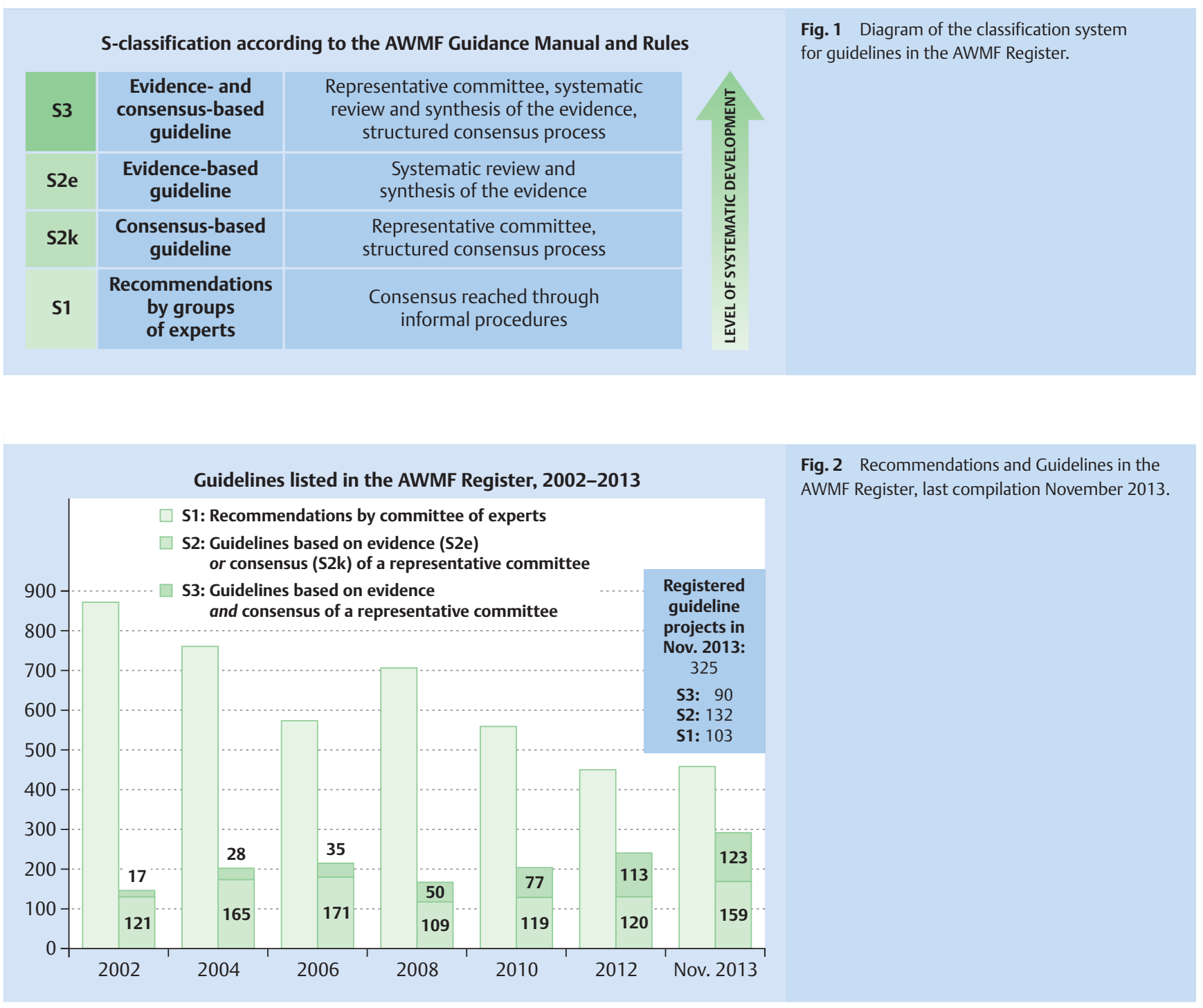

- weigh the benefits and harm of alternative approaches methods and present the results of this weighing up in a transparent manner,

- clarify opposing standpoints,

- take account of the needs and preferences of patients,

- define the current procedure of choice $[11,12]$.

Guidelines must not be viewed as "cookbooks" which take no account of the clinical experience of attending physicians and the individual medical history of patients. Quite the contrary: guidelines must be understood as "treatment and decision corridors" which can or must be deviated from in individual justified cases $[11,14]$.

\section{Guidelines in the AWMF Register:}

\section{categories and quality management rules}

The classification system of the AWMF categorizes recommendations and guidelines as S1, S2e, S2k or S3. Recommendations by experts are classified as level S1. Because these recommendations have not been developed systematically they are not classified as guidelines in the true sense of the word. Level S2 guidelines are based either on a systematic analysis of scientific evidence (S2e guidelines) or on a structured consensus-based agreement between the members of a representative committee
(S2k guidelines). Level S3 guidelines are the highest level and include both aspects [8] ( $\bullet$ Fig. 1 ).

Part of the maintenance of the Guideline Register consists of examining all applications for registration proposed by the AWMFIMWi. The target audience is scrutinized, and a check is run to see whether medical societies of the AWMF have previously addressed any of the individual topics included in the planned guideline or even issued (partial) recommendations. This is done to avoid unresolved contradictions between individual guidelines in the Register and to promote interdisciplinary cooperation between medical societies. All groups applying to register a guideline or recommendation are also offered a free consultation. An additional coordination of registration by the individual medical societies is helful, as is already current practice in the guidelines office of the DGGG.

The completed guideline together with the guideline report, the most recent declaration of conflicts of interest and, where applicable, any other versions in use are submitted to the AWMF and subsequently examined by the AWMF-IMWi. Even after the guideline has been published online in the AWMF Guideline Register, the group which compiled the guideline still holds the copyright to the guideline [13]. The guideline will remain in the Register of the AWMF for a maximum of 5 years. If no update is 


\begin{tabular}{|c|c|c|}
\hline $\begin{array}{l}\text { Cate- } \\
\text { gory }\end{array}$ & $\begin{array}{l}\text { Published guidelines compiled under the aegis of the DGGG } \\
\text { (AWMF Register no.) }\end{array}$ & $\begin{array}{l}\text { Registered guideline projects compiled under the aegis } \\
\text { of the DGGG (AWMF Register no.) }\end{array}$ \\
\hline \multirow[t]{4}{*}{ S3 } & $\begin{array}{l}\text { Treatment of inflammatory breast disease during } \\
\text { the lactation period }(015-071)\end{array}$ & Contraception (015-015) \\
\hline & $\begin{array}{l}\text { Hormone therapy in perimenopause and postmenopause } \\
\qquad(015-062)\end{array}$ & $\begin{array}{l}\text { Diagnostics, treatment and follow-up of women with } \\
\text { cervical cancer (032-033OL) }\end{array}$ \\
\hline & $\begin{array}{l}\text { Malignant ovarian tumors; diagnostics, treatment and } \\
\text { follow-up (032-035OL) }\end{array}$ & $\begin{array}{l}\text { Flap reconstruction in breast cancer } \\
\qquad(015-075)\end{array}$ \\
\hline & $\begin{array}{l}\text { Breast cancer in women: diagnostics, treatment } \\
\text { and follow-up (032-045OL) }\end{array}$ & Prevention of cervical cancer (015-027OL) \\
\hline \multirow[t]{2}{*}{ S2e } & \multirow{2}{*}{ Stress incontinence in women (015-005) } & Uterine prolapse (015-006) \\
\hline & & Hysterectomy: indications and methods (015-070) \\
\hline \multirow[t]{6}{*}{ S2k } & Diagnostics and treatment of endometriosis (015-045) & Chlamydia trachomatis infections (059-005) \\
\hline & \multirow{5}{*}{ The overactive bladder (015-007) } & $\begin{array}{l}\text { Approaches in prolonged and post-term pregnancy } \\
\qquad(015-065)\end{array}$ \\
\hline & & Ultrasound in urogynecological diagnostics (015-055) \\
\hline & & $\begin{array}{l}\text { Psychosomatic diagnostics and treatment of fertility } \\
\text { disorders (016-003) }\end{array}$ \\
\hline & & $\begin{array}{l}\text { Diagnostics and treatment of vulvar cancer and its } \\
\text { precursor lesions (015-059) }\end{array}$ \\
\hline & & Vulvovaginal candidiasis (015-072) \\
\hline
\end{tabular}

Fig. 3 Currently existing and pending S2 and S3 guidelines issued under the aegis of the German Society for Gynecology and Obstetrics (DGGG), December 2013.

filed during this period, the guideline is removed from the Register.

Involvement of medical societies in the guidelines: steady trend towards better quality

Despite the higher demands with regard to methodology compared to S1 recommendations, in the last few years the numbers of S2 and S3 guidelines have steadily increased. In November 2013 the AWMF Guideline Register listed 448 S1 recommendations (compared to $>800 \mathrm{~S} 1$ in 2002), $159 \mathrm{~S} 2 \mathrm{e}+\mathrm{k}$ guidelines (2002: 121 S2) and 123 S3 guidelines (2002: 17 S3) († Fig. 2).

The trend towards more systematic, better quality guidelines is also evident for the German Society for Gynecology and Obstetrics (German: Deutsche Gesellschaft für Gynäkologie und Geburtshilfe, abbreviated DGGG). The S3 guidelines on Breast Cancer Screening and on the Diagnosis, Therapy and Follow-up of Breast Cancer were some of the first S3 guidelines ever published. Since then, they have been augmented by S3 guidelines on hormone therapy in peri- and postmenopause, on the diagnostics and therapy of malignant ovarian cancer and on the treatment of inflammatory breast disease during lactation. An S2e guideline on stress incontinence in women has been completed and the guideline on the diagnosis and treatment of endometriosis has been updated as S2k. The DGGG is additionally involved in 11 S3 guidelines and 9 S2 guidelines. A number of other S2 and S3 guidelines under the aegis of the DGGG have been announced and are currently being developed and revised ( $\bullet$ Fig. 3 ). There are also plans to successively raise the category of guidelines on obstetrical topics (Prof. Dr. M.W. Beckmann, Guidelines Officer of the DGGG, personal communication).

\section{Reliable Information for Practice Use: How Guidelines Are Developed}

The development of a guideline usually occurs in several life phases. Initial life phases include planning and organizing the guideline and applying for the guideline to be registered in the Guideline Register. This is followed by the actual compilation of the guideline, which is then subsequently carefully edited. The next step consists in preparing for its implementation and evaluation $[11,14,15]$. Planning and organization, development of the guideline and preparations for implementation and evaluation are explained in the following sectors. Details on all aspects as well as help and practical advice are available from the AWMF guidance [11].

\section{Planning and organization}

Planning a guideline starts by deciding on the methodological approach ("S category"). This depends on what is practicable and workable given the available resources of time and money.

It is also important to consider additional aspects in advance:

- Choice of a suitable, appropriately delimited topic (assessment of need),

- Definition of concrete goals associated with the introduction of the guideline,

- Formulation of clinically relevant issues which should be discussed in the guideline,

- Definition of who should use the guideline (target audience, other professional groups in addition to physicians, e.g. nurses, physiotherapists, midwives). 
To ensure that the guideline is also accepted in practice, it is useful if the choice of topic can be clearly justified. Concrete examples of potential improvements to healthcare should be given, and the goals which will help achieve such improvements should be clearly described and, if possible, confirmed by data, e.g., the most effective prevention of infections in pregnant women. Defining and limiting the scope of the issue at an early stage is important when planning the literature search, and sensibly limiting the scope of the guideline will make it more attractive. The guideline group needs to involve experienced users and patients to ensure that the guideline's contents are appropriate and sufficient. When compiling the guideline, the question will arise as to "who will be affected by the recommendations". It is generally recommended to involve representatives of target audience in the development of the guideline if they are interested in being involved. Enlisting the help of methodologists is also recommended $[11,15]$.

\section{Disclosing and managing potential conflicts of interest}

The general public is very sensitive to possible distortions of the contents of guidelines because authors of the guideline have conflicts of interest $[16,17]$. According to the rules of the AWMF, guidelines must have independent funding, and conflicts of interest must be reported for every member of the guideline committee. These declarations concerning conflicts of interest must be available prior to starting work on the guideline. The assessment of conflicts of interest and how such conflicts should be handled must be discussed openly, and the rules on how to deal with conflicts of interest must be defined by the guideline group. Benefits and disadvantages should be straightforwardly weighed up against each other. The potential to contribute expert knowledge must be weighed against the risk of distortion. This risk of distortion can be countered by using the "protective" mechanisms proposed in the AWMF rules which include an independent, external review of the evidence and a structured consensus process or regulations such as excluding specific persons from voting or demanding that the final review is carried out by external experts [18]. Ensuring that discussions and procedures are open and transparent inspires trust and is a protection against imputations of bias.

\section{Systematic search and assessment of evidence}

The evidence base and the structured consensus process are important stages in compiling a guideline which aims to find answers to clinical problems. The evidence base and consensus process depend on the category chosen for the guideline. Well prepared "external" evidence, clinical assessment and patient preferences are important pillars of decision-making. When compiling a category S2e or S2k guideline, it is important to settle at the constitutive meeting which strategy will be used to find answers for every issue. Even when drawing up a guideline with systematic evidence base, it is possible to decide at the outset that individual issues will be resolved after consensus has been reached by a committee of experts. Other strategies include adopting already existing recommendations from high quality guidelines or - if such guidelines do not exist or their recommendations are not transferrable - drawing on recent systematic reviews and meta-analyses. If no good sources providing a good overview of the existing evidence are available, it will be necessary to systematically search for primary studies and evaluate them [19].

\section{Structured process to reach consensus}

The AWMF rules state that level S2k and S3 guidelines require a structured process to achieve consensus and that this process should be used in group communications at face-to-face meetings chaired by a neutral moderator. The approach used can consist either of the formal methods of nominal group processes or of a structured consensus conference. The aim is to ensure that every member of the guideline group can contribute an opinion without hindrance and that neither a majority nor a minority will dominate the procedure. The goal is to resolve problems that need deciding and come to a final assessment of recommendations. The level of recommendation (should, ought to, may be considered) is decided on and the strength of the consensus is determined. Another formal method of reaching consensus is through written anonymous voting (DELPHI method) [11].

\section{Editing - benefits of using several different formats for implementation}

Recommendations should be worded unambiguously and should be well presented to ensure that the recommendations are comprehensible and attractive for users and that users consider them reliable. Different user versions are useful to encourage the dissemination and implementation of a guideline. These different versions include a long version with background information, tables of evidence and a guideline report for readers interested in the methodology or in obtaining more information. A short version with a summary of the recommendations and clearly arranged flow diagrams showing the optimal course of treatment (clinical algorithms) are extremely useful as they provide quick access to information in practice. User versions include reprints in professional journals, practical guides on how to implement the recommendations, pocket-sized versions, training materials such as mounted slides or transparencies and, not least, versions for patients. Electronic guideline aids (e.g. Apps) or electronic decision systems can contribute to the dissemination of guidelines.

\section{Implementation and Evaluation \\ $\nabla$}

Implementation consists of the difficult task of translating recommendations on how to act into concrete individual actions and, if necessary, inducing changes in behavior [20,21]. Obstacles to implementation include reservations about implementing the goals and organizational, structural, personal and/or financial barriers. It is important to identify such obstacles and offer suggestions for solution. In most cases, the guideline group can only encourage widespread implementation by following best practice rules when developing, editing and disseminating the guideline and promoting outreach. In the end, it is necessary that target audiences and the users themselves discuss the guideline in the light of their own experience and their own knowledge of the literature and of local circumstances and develop implementation strategies adapted to their environment. A number of strategies have proved to be useful $[22,23]$. Widespread dissemination of a guideline adapted to its respective target groups and the support of opinion leaders ("implementation is a top priority") is important as well as the involvement of "multipliers" [24]. The extent of implementation of a guideline and the impact on healthcare can be measured using quality indicators based on accepted methodological standards and proposed by the authors of the guideline $[25,26]$. Assessment should be limited to the most important aspects; it is important to remember that users must 
benefit from participating in documentation, at the very least by receiving feedback about the results [14]. The time spent on documentation and on fulfilling regulatory requirements are already experienced as a big problem. Whether implementation of a guideline is associated with improved outcomes can only be proved by data collection as the BRENDA study demonstrated for breast cancer patients [27]. User feedback makes it possible to evaluate to what extent recommendations in guidelines are (or can be) implemented in specific patient groups and whether recommendations need to be adapted to the needs of specific groups [28]. A systematic exchange of information between authors of guidelines and users after publication and implementation of the guideline is essential to take account of any problems arising during implementation and incorporate them in the revised guideline [29]. To avoid the number of guidelines expanding too much and becoming confusing, the selection of suitable topics for guidelines and guideline contents should be periodically reviewed. When drawing up a guideline, it is important to appoint a person to be contacted for updating the guideline, and it should be decided in advance which trigger will lead to the guideline being amended.

\section{Conclusion}

$\nabla$

- Guidelines serve to communicate current knowledge and as aids to decision-making for specific patients and aim to ensure that the best possible healthcare will be provided.

- The Guideline Register of the AWMF is compiled according to specific rules; every guideline is evaluated whether it complies with the methodological standards of the category it is assigned to. The AWMF supports developers of guidelines with its AWMF rules and by offering consultations.

- Reliable guidelines have a transparent methodology. The methodology used for the evidence base and/or to determine how a consensus is reached depends on the guideline's S category. Conflicts of interest are always disclosed, irrespective of the guideline's category.

- The makers of guidelines need feedback obtained from practical experience if the recommendations in the guidelines cannot be applied or cannot be applied to all patients. Therefore the name of the person who will be responsible for updating the guideline is always included.

- The commitment and dedication of medical societies and of the unpaid authors who volunteer to compile guidelines have contributed to the success of the quality initiative "Guidelines" of the AWMF Register to improve clinical care.

\section{Conflict of Interest}

$\nabla$

The author Dr. Nothacker works for the IMWi.

\section{References}

1 AWMF, Hrsg. 50 Jahre AWMF - Aufgaben, Ziele und Aktivitäten. Düsseldorf 2012, ISBN 978-3-88681-115-1. Online: http://www.awmf.org/ fileadmin/user_upload/Die_AWMF/AWMF_aktuell/2012/Broschuere_ 50_Jahre_AWMF.pdf; last access: 11.10.2013

2 AWMF, Hrsg. AWMF-Stellungnahmen und Resolutionen. Online: http:// www.awmf.org/die-awmf/awmf-stellungnahmen.html; last access: 10.12.2013

3 Gemeinsamer Bundesausschuss (G-BA). Stellungnahmeberechtigte zu den Richtlinien gemäß §§ 135, 137c und 137e SGB V (1/2012). Online: http://www.g-ba.de/downloads/17-98-3506/SN-Berechtigte_135137c-137e.pdf; last access: 10.12.2013

4 Sachverständigenrat für die konzertierte Aktion im Gesundheitswesen, Hrsg. Gesundheitsversorgung und Krankenversicherung 2000 - Mehr Ergebnisorientierung, mehr Qualität und mehr Wirtschaftlichkeit, Kurzfassung und Empfehlungen, 1995

5 IOM (Institute of Medicine). Clinical Practice Guidelines we can trust. Washington, DC: The Nationale Academies Press; 2011; Online: www. iom.edu

6 Dunkelgrun M, Boersma E, Schouten O et al.; Dutch Echocardiographic Cardiac Risk Evaluation Applying Stress Echocardiography Study Group. Bisoprolol and fluvastatin for the reduction of perioperative cardiac mortality and myocardial infarction in intermediate-risk patients undergoing noncardiovascular surgery: a randomized controlled trial (DECREASE-IV). Ann Surg 2009; 249: 921-926

7 Erasmus Medical Center. Follow up study on scientific integrity (2012). Online: http://www.erasmusmc.nl/corp_home/corp_news-center/ 2012/2012-10/vervolg.onderzoek.wetenschappelijke.integriteit/ ?lang=en; last access: 10.12.2013

8 Doshi P, Jefferson T, Del Mar C. The imperative to share clinical study reports: recommendations from the Tamiflu experience. PLoS Med 2012; 9: e1001201

9 Europarat; Verbindung der Schweizer Ärztinnen und Ärzte; Ärztliche Zentralstelle Qualitätssicherung; Ludwig Boltzmann Institut für Krankenhausorganisation. Entwicklung einer Methodik für die Ausarbeitung von Leitlinien für optimale medizinische Praxis. Empfehlung Rec (2001) 13 des Europarates am 10. Oktober 2001 und Erläuterndes Memorandum. Deutschsprachige Ausgabe. Z Arztl Fortbild Qualitatssich 2002; 96 (Suppl. III): 3-60

10 Qaseem A, Forland F, Macbeth F et al.; for the Board of Trustees of the Guidelines International Network. Guidelines International Network: toward international standards for clinical practice guidelines. Ann Intern Med 2012; 156: 525-531

11 Muche-Borowski C, Selbmann HK, Nothacker M et al.; Arbeitsgemeinschaft der Wissenschaftlichen Medizinischen Fachgesellschaften (AWMF); Ständige Kommission Leitlinien, Hrsg. AWMF-Regelwerk „Leitlinien“. 1. Auflage. Germering: Zuckschwerdt Verlag; 2012

12 Bundesärztekammer (BÄK); Arbeitsgemeinschaft der Wissenschaftlichen Medizinischen Fachgesellschaften (AWMF); Kassenärztliche Bundesvereinigung $(\mathrm{KBV})$. Nationales Programm für Versorgungs-Leitlinien. 2010. Methoden-Report. 4. Aufl., Version 1.0, Juli 2010. Online: http:// www.versorgungsleitlinien.de; last access: 10.12.2013

13 Wienke A, Nölling T. Urherberrechte an medizinisch-wissenschaftlichen Leitlinien: Rechteinhaber, Rechteverwertung und Rechteübertragung. GMS. Mitteilungen AWMF 2012; 9: Doc17

14 Kopp I. Von Leitlinien zur Qualitätssicherung. Bundesgesundheitsbl 2011; 54: 160-165

15 Muche-Borowski C, Kopp I. Wie eine Leitlinie entsteht. Z Herz-ThoraxGefäßchir 2011; 25: 217-223

16 Lenzen-Schulte M. Was die Leitlinien Ärzten verschweigen. Frankfurter Allgemeine Zeitung, Natur und Wissenschaft, 28.08.2013. Online: http://www.bda.de/aktuelles/Frankfurter_Allgemeine_Zeitung_ 28.08.2013.pdf; last access: 10.12.2013

17 Kuhrt N. Gefährliche Tricks: Leitlinien für Ärzte sind anfällig für Manipulation. Spiegel Online Wissenschaft, 16.10.2013. Online: http:// www.spiegel.de/wissenschaft/medizin/leitlinien-streit-verzerrtedaten-beeinflussen-empfehlungen-a-926041.html; last access: 10.12.2013

18 Kreienberg R, Kopp IB. Risikobewusstsein und Transparenz etabliert. Dtsch Arztebl Int 2013; 110: 286-287 
19 Deutsches Cochrane-Zentrum; Arbeitsgemeinschaft der Wissenschaftlichen Medizinischen Fachgesellschaften; Institut für Medizinisches Wissensmanagement; Ärztliches Zentrum für Qualität in der Medizin. „Manual Systematische Literaturrecherche für die Erstellung von Leitlinien“. 1.Aufl. 2013. Online: http://www.awmf.org/fileadmin/ user_upload/Leitlinien/Werkzeuge/20130523_Manual_ Literaturrecherche_Final.pdf; last access: 10.12.2013

20 Cabana MD, Rand CS, Powe NR et al. Why don't physicians follow clinical practice guidelines? A framework for improvement. JAMA 1999; 282: 1458-1465

21 Schubert I, Egen-Lappe V, Heymans L et al. ['To read' does not imply 'to act upon': indicators of the acceptance of general practice guidelines. Results of a survey among quality circles of general practitioner centred care (Hausarztzentrierte Versorgung; HZV)]. Z Evid Fortbild Qual Gesundhwes 2009; 103: 5-12

22 Grimshaw JM, Thomas RE, MacLennan G et al. Effectiveness and efficiency of guideline dissemination and implementation strategies. Health Technol Assess 2004; 8: 1-72

23 Francke AL, Smit MC, de Veer AJ et al. Factors influencing the implementation of clinical guidelines for health care professionals: a systematic meta-review. BMC Med Inform Decis Mak 2008; 8: 38
24 Nothacker M, Muche-Borowski C, Kopp I et al. On the attractiveness, implementation and evaluation of guidelines. Z Evid Fortbild Qual Gesundhwes 2013; 107: 164-169

25 Programm für Nationale VersorgungsLeitlinien von BÄK, KBV und AWMF; Qualitätsindikatoren - Manual für Autoren. äzq-Schriftenreihe Band 36, 2009

26 Nothacker M], Langer T, Weinbrenner S. [Quality indicators for National Disease Management Guidelines using the example of the National Disease Management Guideline for "Chronic Heart Failure"]. Z Evid Fortbild Qual Gesundhwes 2011; 105: 27-37

27 Wöckel A, Kurzeder C, Geyer V et al. Effects of guideline adherence in primary breast cancer - a 5-year multi-center cohort study of 3976 patients. Breast 2010; 19: 120-127

28 Schwentner L, Wöckel A, König J et al. Adherence to treatment guidelines and survival in triple-negative breast cancer: a retrospective multi-center cohort study with 9156 patients. BMC Cancer 2013; 13: 487

29 Albert US, Koller M, Lorenz W et al. [A concept for the implementation and evaluation of the guideline "Early Detection of Breast Cancer in Germany"]. Z Arztl Fortbild Qualitatssich 2004; 98: 347-359 